dr inż. Marek Sobaś

Instytut Pojazdów Szynowych „,TABOR”

\title{
Badania wytrzymałościowe wózka 11 ANC
}

\begin{abstract}
W artykule przedstawiono program badań wytrzymałościowych ramy wózka 11ANc, jako podstawowego ustroju nośnego. Opisano ramę jako obiekt do badań, strukturę stanowiskowych badań wytrzymałościowych, specyfikację sit działajacych na ramę oraz kryteria oceny wyników badań. Artykut powstat w ramach projektu badawczo-rozwojowego $\mathrm{nr}$ R10 041 02, finansowanego przez Ministerstwo Nauki i Szkolnictwa Wyższego ze środków

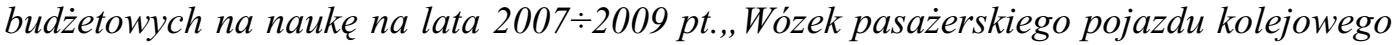
typu Z o prędkości $250 \mathrm{~km} / \mathrm{h}$ i możliwości modyfikacji do prędkości $300 \mathrm{~km} / \mathrm{h}$ ”.
\end{abstract}

\section{Wstęp}

Wózki toczne dla wagonów osobowych, przystosowane do wysokich prędkości powyżej $250 \mathrm{~km} / \mathrm{h}$ muszą spełniać szereg wymagań przepisów międzynarodowych, zawartych w kartach UIC, normach europejskich EN, opracowanych przez Europejski Komitet Normalizacyjny (fr. „Comité Européen de Normalisation",ang. European Committee for Standardization, niem. Europeisches Komitee für Normung). Istotny wkład w zakres przepisów obowiązujących dla poszczególnych komponentów wózka wnosi norma prPN-EN 15827:2008 [28]. Jednym z najważniejszych badań komponentów wózka jest badanie ramy jako podstawowego i najbardziej złożonego ustroju nośnego układu biegowego pod względem budowy. Problem ten nabiera szczególnego znaczenia dla układów biegowych dla wagonów osobowych zwłaszcza, że wózek jest przeznaczony do wysokich prędkości tzn. do $250 \mathrm{~km} / \mathrm{h}$, z możliwością modyfikacji do $300 \mathrm{~km} / \mathrm{h}$. Takie komponenty jak rama wózka, sprężyny zawieszenia pierwszego i drugiego stopnia, wahacz i zestaw kołowy, podlegające obciążeniom dynamicznym powinny wykazać się dużym stopniem niezawodności i wykazywać dostateczną wytrzymałość zmęczeniową

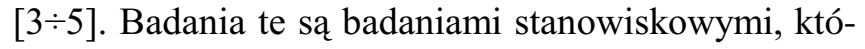
re przeprowadza się na prototypie ramy wózka. Decyzja o podjęciu badań stanowiskowych powinna być poprzedzona obliczeniami metodą elementów skończonych wg licencjonowanego programu $\mathrm{z}$ uwzględnieniem wszystkich sił działających na ramę wózka. Celem badań stanowiskowych jest udowodnienie poprawności rozwiązań konstrukcyjnych oraz zastosowanej technologii producenta, zwłaszcza technologii spawania, która mimo istotnego postępu w zakładach produkujących musi być weryfikowana nie tylko przez kontrolę jakości producenta przy zastosowaniu tradycyjnych metod badań spoin, do jakich należy zaliczyć badań badania wizualne, nowoczesne metody ultradźwiękowe, rentgenograficzne (badania stosowane przez kontrolę jakości producenta). W przypadku zmiany producenta, badania stanowiskowe należy powtórzyć.
Badania stanowiskowe należy przeprowadzić na jednej ramie prototypowej, która po badaniach wytrzymałościowych musi być złomowana. W związku z powyższym, koszty stanowiskowych badań wytrzymałościowych są bardzo duże. Aby uniknać ich powtórzenia należy przedsięwziać kwalifikację obiektu do badań przez zastosowanie badań metodą proszków magnetycznych spoin wózka przez akredytowane laboratorium badawcze. W przypadku stwierdzenia nieprawidłowości można podjąć decyzję o ewentualnej naprawie spoin przez producenta, których jakość budzi wątpliwość i może mieć wpływ na negatywny wynik badań.
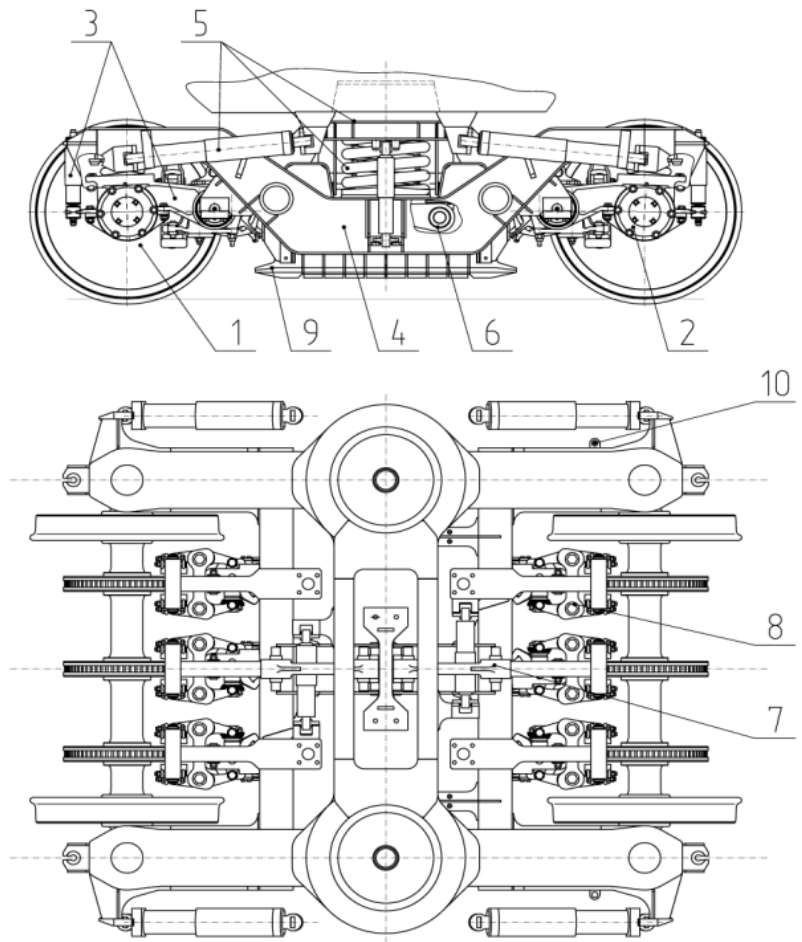

Rys.1. Wózek 11ANc przystosowany do wysokich prędkości (widok z boku i z góry). Oznaczenia użyte na rys.1:

1- zestaw kołowy z maźnicami i z trzema tarczami hamulcowymi 2- maźnice 
3- uktad usprężynowania pierwszego stopnia i prowadzenie maźnicy

4- rama wózka wraz ze wspornikami jako częściami przyspawanymi

5- belka nadwózkowa, usprężynowanie drugiego stopnia, tlumiki wężykowania

6- fragment stabilizatora przechylania

7- urzadzenie pociagowe

8- mechanizm zaciskowy hamulca tarczowego

9- elektromagnetyczny hamulec szynowy

10- ogranicznik przesuwu i skrętu wózka.

Widok wózka 11 ANc ze strony czołowej przedstawiono na rys.2.

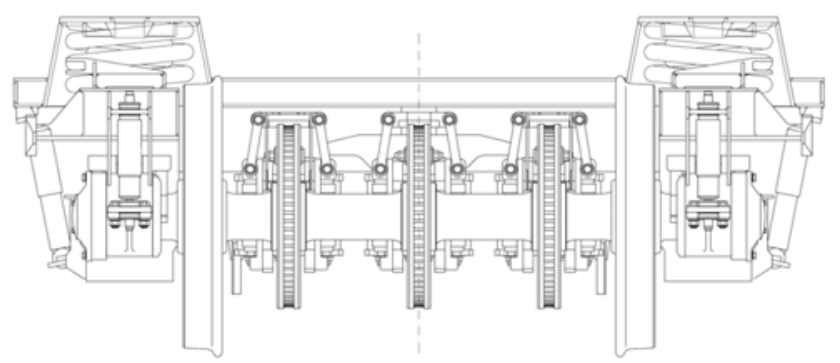

Rys.2. Wózek 11ANc przystosowany do wysokich prędkości (widok od strony czołowej)

\section{Obiekt do badań \\ 2.1. Opis ogólny}

Obiektem do stanowiskowych badań wytrzymałościowych jest prototypowa rama wózka $11 \mathrm{ANc}$, który jest przeznaczony do wagonów osobowych typu Z wg karty UIC 567-2 [13] przystosowanych do wysokich prędkości zgodnie z wymaganiami karty UIC 660 [14] przez zastosowanie środków konstrukcyjnych w pudle określonych w [7,8]. Konstrukcja wózka z podziałem na grupy konstrukcyjne została szczegółowo omówiona i przedstawiona w [4]. Widok ogólny wózka $11 \mathrm{ANc}$ jest przedstawiony na rys. 1 i 2 .

Wózek spełnia wymagania skrajni kinematycznej wg karty UIC 505-1 [9], natomiast jego podstawowe komponenty jak koła, osie i spełniają wymagania odpowiednio karty UIC 510-2 [10] i PN-EN 13715:2006 [20] (zarys zewnętrzny wieńca koła), PN-EN 13262:2007 [19] (wymagania konstrukcyjne koła) oraz PN-EN 13103:2003 [17] (wytrzymałość osi) i PN-EN 13261:2004 [18].

Rama wózka jest konstrukcją spawaną, składającą się z dwóch ostojnic o zamkniętej konstrukcji skrzynkowej, połączonych dwoma rurami do mocowania mechanizmów zaciskowych hamulca tarczowego. Rury są połączone wzdłużną belką centralną do przeniesienia siły pociagowej wózek-pudło wagonu osobowego. Na ramę wózka użyto półwyrobów (blach i kształtowników) ze stali S355 wg PN-EN 100025-2:2007 [16], posiadającej granicę plastyczności $R_{e}=355 \mathrm{MPa}$ oraz doraźną granicę na rozciaganie $\mathrm{R}_{\mathrm{m}}=520 \mathrm{MPa}$. Konstrukcja ramy wózka jest przestawiona na rys.3.

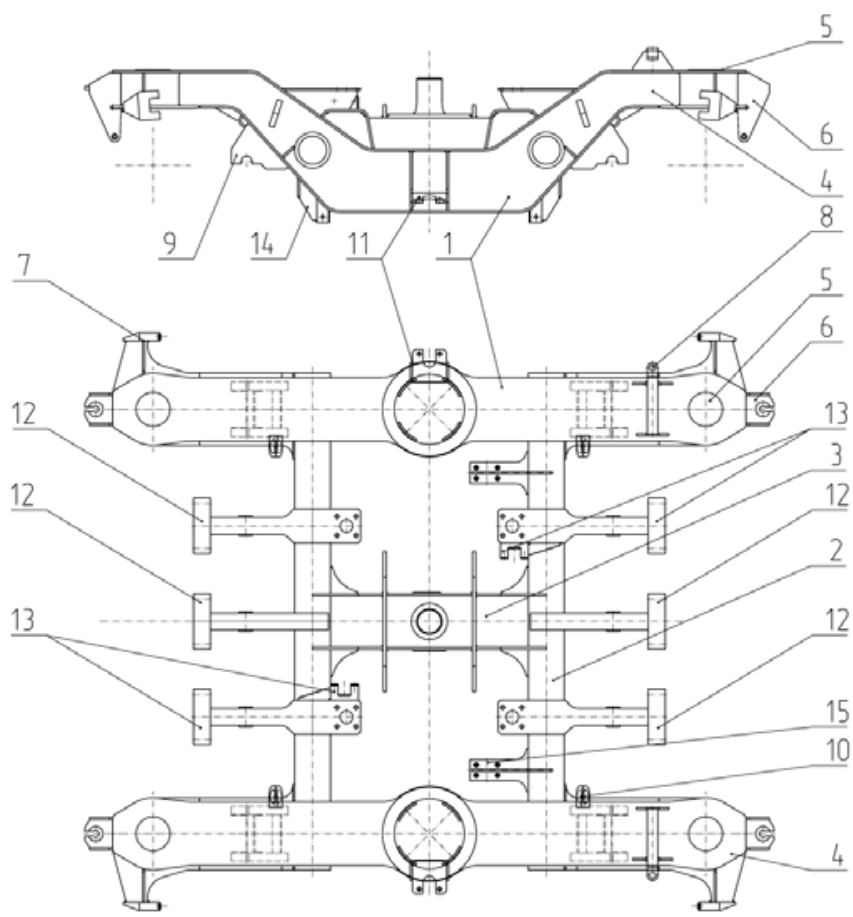

Rys.3. Rama wózka 11Anc. Oznaczenia na rys.3:

1- ostojnica

2- poprzecznica $w$ ksztatcie rury

3- $\quad$ wzdlużna belka centralna do przeniesienia sity pociagowej

4- gniazda sprężyn

5- płyty bazowe slużqce do podpory ramy podczas obróbki mechanicznej

6- $\quad$ wspornik amortyzatora usprężynowania pierwszego stopnia

7- wspornik amortyzatora wężyowania

8- wspornik ogranicznika przesuwu poprzecznego

9- $\quad$ wspornik do mocowania wahaczy maźniczych, wykonanych ze staliwa wg PN-ISO 3755:1994 [29]

10- wsporniki transportowe na ściankach bocznych

11- wspornik amortyzatora pionowego

12- wspornik przeznaczone do zawieszenia hamulca tarczowego $i$ szynowego

13- wspornik do zamocowania amortyzatora poziomopoprzecznego i do zawieszenia hamulca tarczowego i szynowego

14- wspornik do zamocowania prowadzenia płóz elektromagnetycznych hamulca szynowego

15- wspornik do zamocowania podpór stabilizatora przechylania.

Konstrukcja ramy wózka jest przystosowana do przenoszenia wszystkich sił pojawiających się w eksploatacji tzn. sił pionowych, sił poprzecznych, sił wichrowatości toru, sił hamulcowych i pochodzących od nabiegania, zdefiniowanych w PN-EN 13749:2008 [21], które pojawiają się jako statyczne siły nadzwyczajne oraz obciążenia cykliczne, wywołujące stopniowe zmęczenie struktury nośnej, które nie powinno prowadzić do pęknięć lub uszkodzeń struktury nośnej w zakładanym okresie użytkowania wagonu osobowego. Dla ustabilizowania wymiarów wózka po spawaniu przewidziano usunięcie głównych naprężeń spawalniczych poprzez poddanie działania odpowiedniego obciążenia stabilizującego lub poprzez odprężanie wibracyjne. Odprężanie wibracyjne jest metodą coraz bardziej preferowaną i wyżej ocenianą pod względem skuteczności usuwania naprężeń spawalniczych (szczątkowych) w ramach wózków. 


\subsection{Kwalifikacja i wymagany stan obiektu do ba- dań}

Rama przeznaczona do badań powinna być wyposażona we wszystkie przyspawane wsporniki zgodnie z dokumentacją konstrukcyjną. Rama po odbiorach przez Dział Kontroli Jakości oraz przedstawiciela użytkownika-klienta powinna być dostarczona do badań w stanie zagruntowanym. Spoiny powinny być wykonane zgodnie z wymaganiami karty UIC 897-13 [15] lub pakietu norm PN-EN 15085 część $1 \div 5$ [2327].

Kwalifikacja obiektu do badań stanowiskowych przez laboratorium badawcze polega na:

$>$ sprawdzeniu przez laboratorium badawcze kompletności dostarczonych dokumentów odbiorczych dostarczonych przez producenta

$>$ przeprowadzeniu oględzin obiektu okiem nieuzbrojonym

> sprawdzeniu zgodności obiektu z dokumentacją konstrukcyjną i kompletności przyspawanych wsporników, ciągłość spoin

$>$ ocenie jakości spoin metodą wizualną VT, metodą magnetyczno-proszkową MT lub metodą penetracyjną PT przez pracownika lub instytucję zewnętrzną, posiadającą uprawnienia i wystawienie protokołu z przeprowadzonych badań.

\section{Stanowiskowe badania wytrzymałościowe 3.1. Cel badań stanowiskowych}

Zgodnie z normą EN 13749:2008[21] wózek 11 ANc należy zakwalifikować do kategorii B-I, która obejmuje wózki z przeznaczeniem do eksploatacji na głównych liniach kolejowych oraz wózki do pojazdów szynowych do przewozów pasażerskich, wliczając pojazdy szynowe dostosowane do wysokich prędkości, napędne lub toczne. Stanowiskowe badanie wytrzymałościowe należy przeprowadzić zgodnie z programem badań, który jest opracowany $\mathrm{w}$ oparciu o wytyczne normy europejskiej EN 13749:2008 [18], karty UIC 515-4 [9], raportów ORE/ERRI B12 Rp.17 [32] i ORE/ERRI B12 Rp.60 [33]. W związku ze wzrostem znaczenia przepisów TSI (ang. Technical Specification for Interoperability”, niem. „Technische Spezifikation der Interoperabilität") zasadniczym dokumentem, który należy uwzględnić przy opracowaniu programu stanowiskowych badań wytrzymałościowych jest norma europejska EN13749:2008 [21].

Celem stanowiskowych badań wytrzymałościowych jest:

$>$ symulacja przypadków obciążeń, które mogą wystapić w eksploatacji

$>$ ustalenie wartości i rozkładu naprężeń w ramie dla zadanych obciążeń przy pomocy tensometrów

$>$ sprawdzenie wytrzymałości zmęczeniowej ramy

> określenie fragmentów ramy, którym należy poświęcić szczególną uwagę przy produkcji, kontroli i przeglądach okresowych (naprawach taboru) sprawdzenie, czy technologia stosowana przez producenta $\mathrm{w}$ procesie produkcji ramy wózka spełnia wymagania konstrukcyjne.

\subsection{Struktura stanowiskowych badań wytrzymało ściowych}

Próby wytrzymałościowe ramy wózka należy przeprowadzić w dwóch niezależnych etapach badawczych:

badania statyczne $\mathrm{z}$ obciążeniami nadzwyczajnymi, występującymi w eksploatacji

> badania statyczne z obciążeniami eksploatacyjny$\mathrm{mi}$

> badania zmęczeniowe $\mathrm{z}$ obciążeniami eksploatacyjnymi.

Warunkiem realizacji kolejnego etapu badawczego jest pozytywny wynik etapu poprzedniego. Wyniki każdego $\mathrm{z}$ etapów należy oceniać $\mathrm{w}$ oparciu o obowiązujące kryteria, które zostaną przedstawione w dalszej części opracowania.

Obydwie próby należy przeprowadzić przy użyciu tensometrów.

Tensometry należy rozmieścić w tych rejonach ramy, w których:

> występują naprężenia o dużej wartości na podstawie obliczeń wykonanych metodą elementów skończonych, które są przedstawione w dokumencie OR-9257 [1] oraz usytuować na

$>$ jednej połowie ramy, natomiast na drugiej powinny być umieszczone tensometry kontrolne, celem zweryfikowania wyników pomiarów.

Tensometry o długości pomiarowej $10 \mathrm{~mm}$ (bazie pomiarowej) należy umieścić w taki sposób, aby nie wpłynęły na wyniki badań zmęczeniowych. Powyższy wymóg jest uzasadniony tym, że miejsca pod tensometry muszą być dokładnie oszlifowane przed ich naklejeniem, natomiast wytrzymałość zmęczeniowa jest zależna od chropowatości powierzchni. Zależność ta jest przedstawiona jako funkcja współczynnika stanu powierzchni $\beta_{\mathrm{P}}$ od rodzaju obróbki powierzchniowej na rys.4.

W miejscach, w których główny kierunek naprężeń jest trudny do określenia należy użyć rozety tensometryczne. Usytuowanie tensometrów w rejonie karbów musi być zgodne $\mathrm{z}$ wytycznymi raportu ORE/ERRI B12 Rp.60 [33].

\subsection{Etapy badawcze, wyznaczanie sil badawczych, przebieg badań oraz kryteria oceny}

\subsubsection{Uwagi ogólne}

W celu określenia sił działających w poszczególnych etapach badawczych przyjęto układ współrzędnych zgodnie z PN-EN 13749:2008 [21], który jest przedstawiony na rys.5. 


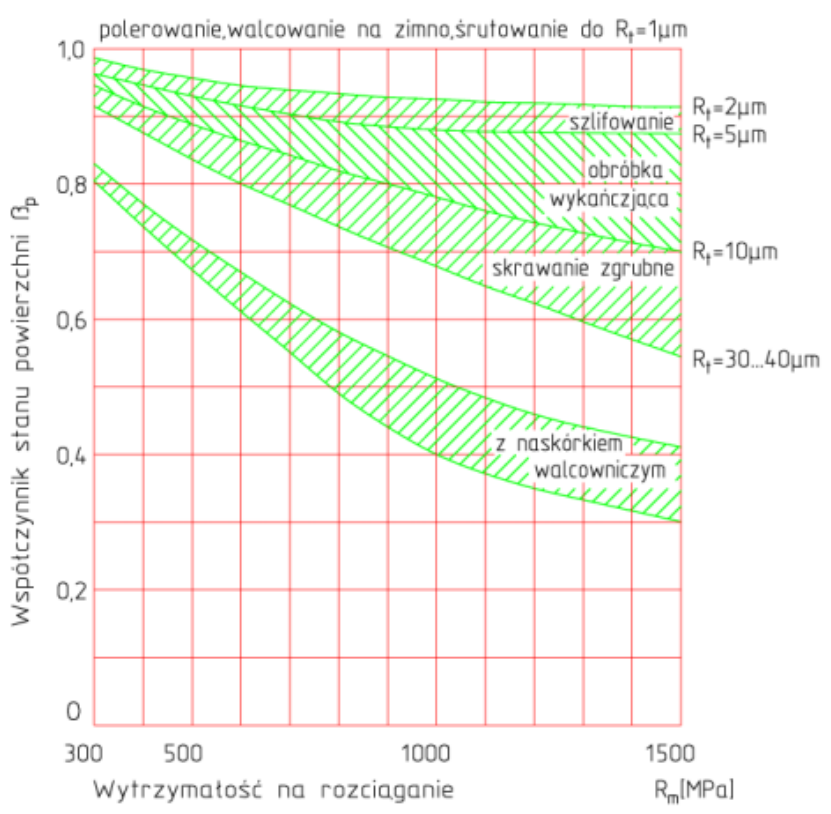

Legenda: $\mathrm{R}_{\mathrm{t}}$ - średnia wysokość nierówności

Rys.4. Zależność współczynnika stanu powierzchni $\aleph_{\mathrm{P}}$ od rodzaju obróbki powierzchniowej i doraźnej wytrzymałości na rozciaganie $R_{m}$ wg [6]

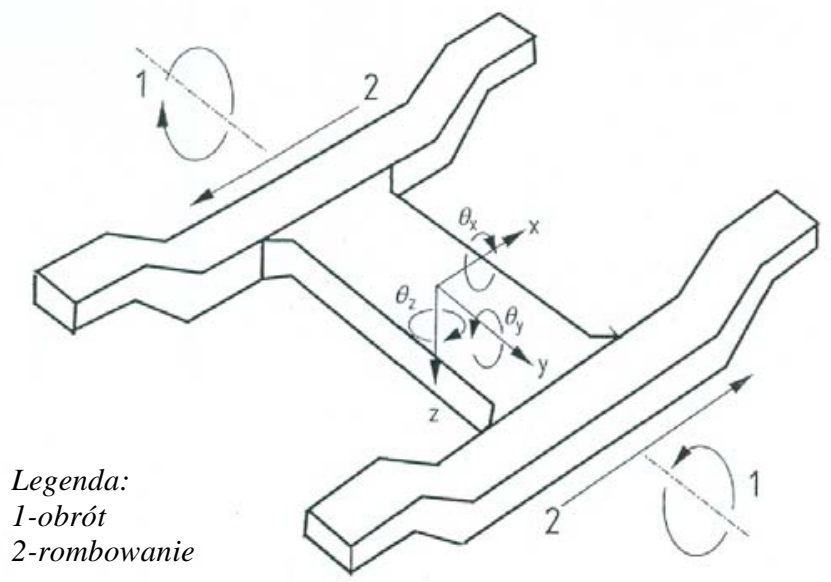

Rys.5. Układ współrzędnych przyjęty do określenia sił w poszczególnych próbach statycznych oraz zmęczeniowych ramy prototypowej wózka 11ANc wg EN 13749:2008[21]

\subsubsection{Wartości liczbowe parametrów, służących do ustalania sil w poszczególnych etapach badań statycznych i zmęczeniowych}

Dane techniczne wagonu osobowego $150 \mathrm{C}$, wyposażonego w dwa prototypowe wózki „11ANc" uwzględnione do wyznaczenia sił użytych podczas badań statycznych i zmęczeniowych ramy wózka wg OR-9257 [1]:

$\Rightarrow$ masa wagonu $\mathrm{M}_{\mathrm{r}}$ $.49200 \mathrm{~kg}$

$\Rightarrow$ masa wózka $\left(\mathrm{m}^{+}\right)$ $.7700 \mathrm{~kg}$

$\Rightarrow$ masa kompletnego zestawu $\mathrm{z}$ prowadnica-

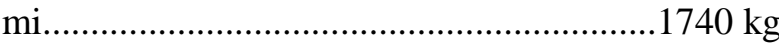

$\Rightarrow$ masa obciążenia nadzwyczajnego $\left(\mathrm{P}_{1}\right) \ldots 14800 \mathrm{~kg}$

$\Rightarrow$ ilość miejsc siedzących. .80

$\Rightarrow$ masa obciążenia eksploatacyjnego $\left(\mathrm{P}_{2}\right) \ldots .10600 \mathrm{~kg}$

$\Rightarrow$ powierzchnia korytarzy...........................17,3 m

$\Rightarrow$ sztywność usprężynowania I-go stopnia........1013 $\mathrm{N} / \mathrm{mm}$

$\Rightarrow$ sztywność usprężynowania II-go stopnia....460,08 $\mathrm{N} / \mathrm{mm}$

$\Rightarrow$ baza wózka (2a)...................................22600 mm

$\Rightarrow$ rozstaw sprężyn $(2 \mathrm{~b}) \ldots \ldots \ldots \ldots \ldots \ldots \ldots \ldots \ldots \ldots . . .2000 \mathrm{~mm}$

$\Rightarrow$ rozstaw kręgów tocznych (2s)................1500 mm

\subsubsection{Badania statyczne ramy wózka $z$ obciąże- niami nadzwyczajnymi}

\subsubsection{Sily podczas badań}

Podczas prób z siłami nadzwyczajnymi należy realizować następujące przypadki obciążeń:

$\Rightarrow$ nadzwyczajne obciążenie pionowe $\mathrm{F}_{\mathrm{z} 1 \max }$

$\Rightarrow$ nadzwyczajne obciążenia pionowe $\mathrm{F}_{z 1 \max } \mathrm{i}$ poprzeczne $\mathrm{F}_{\mathrm{y} 1 \max }$

$\Rightarrow$ nadzwyczajne obciążenie pionowe i poprzeczne oraz od wichrowatości toru $\pm 10 \%$

$\Rightarrow$ obciążenie nadzwyczajne pionowe i od nabiegania

$\Rightarrow$ wykolejenie wózka (wichrowatość) przy obciążeniu pionowym wagonu w stanie próżnym

$\Rightarrow$ obciążenia hamowania.

Oznaczenia użyte na rys.5, opisujące układ współrzędnych są przedstawione w tabeli 1 .

Oznaczenia użyte w określeniu układu współrzędnych przyjęte do wyznaczania sił działających w próbach statycznych oraz zmęczeniowych

Tabela 1

\begin{tabular}{|c|c|c|c|}
\hline L.p. & Kierunek & Symbol & Opis \\
\hline 1. & wzdłużny & $\mathrm{x}$ & liniowy w kierunku toru (jazdy) \\
\hline 2. & poprzeczny & $\mathrm{y}$ & liniowy, równoległy do poziomu toru, prostopadle do kierunku ruchu \\
\hline 3. & pionowy & $\mathrm{z}$ & liniowy \\
\hline 4. & toczenie & $\Theta_{\mathrm{x}}$ & obrót wokół osi wzdłużnej x \\
\hline 5. & pochylanie & $\Theta_{\mathrm{y}}$ & obrót wokół osi poprzecznej y \\
\hline 6. & odchylenie od kierunku & $\Theta_{\mathrm{z}}$ & obrót wokół osi pionowej z \\
\hline 7. & skręt & - & moment w płaszczyźnie (x-y) wynikający ze względnego obrotu \\
& & - & ostojnic \\
\hline 8. & rombowanie & \multicolumn{2}{c|}{} \\
\hline
\end{tabular}


Pionowe obciążenia nadzwyczajne przyłożone do każdej ostojnicy wynosi odpowiednio:

$$
\mathrm{F}_{\mathrm{Z} 1 \max }=\frac{1,4 \cdot \mathrm{g} \cdot\left(\mathrm{M}_{\mathrm{V}}+\mathrm{P}_{1}-2 \mathrm{~m}^{+}\right)}{4}
$$

Po wstawieniu wartości liczbowych $\mathrm{g}=9,81 \mathrm{~m} / \mathrm{s}^{2}$, $\mathrm{M}_{\mathrm{v}}=49200 \mathrm{~kg}, \mathrm{P}_{1}=14800 \mathrm{~kg}, \mathrm{~m}^{+}=7700 \mathrm{~kg}$ do wzoru (1), pionowe obciążenie eksploatacyjne wynosi odpowiednio:

$\mathrm{F}_{\mathrm{ZI} \max }=\mathrm{F}_{\mathrm{z2} \max }=\frac{\mathrm{F}_{\text {zmax }}}{2}=\frac{1,4 \cdot 9,81 \cdot(49200+14800-2 \cdot 7700)}{4}=166868,1 \mathrm{~N}$

Poprzeczne obciążenie działające na zestaw kołowy:

$$
\mathrm{F}_{\mathrm{y} 1 \max }=\mathrm{F}_{\mathrm{y} 2 \max }=\frac{\mathrm{F}_{\mathrm{ymax}}}{2}=10^{4}+\frac{\left(\mathrm{M}_{\mathrm{V}}+\mathrm{P}_{1}\right) \cdot \mathrm{g}}{12}
$$

Po wstawieniu wartości liczbowych $\mathrm{g}=9,81 \mathrm{~m} / \mathrm{s}^{2}$, $M_{v}=49200 \mathrm{~kg}$ oraz $\mathrm{m}^{+}=7700 \mathrm{~kg}$ do wzoru (3) otrzymuje się:

$$
\mathrm{F}_{\mathrm{X} \max }=10^{4}+\frac{(49200+14800) \cdot 9,81}{12}=62320 \mathrm{~N}
$$

Siły działające na wózek wynikające $\mathrm{z}$ przyspieszenia $5 \mathrm{~g}=49,05 \mathrm{~m} / \mathrm{s}^{2}$, powstajace przy nabieganiu wagonu mają charakter sił działających w kierunku wzdłużnym.

Wzdłużne siły działające na wózek określa się ze wzoru:

$$
\mathrm{F}_{\mathrm{x} 1 \max }=0,1 \cdot\left(\mathrm{F}_{\mathrm{zmax}}+\mathrm{m}^{+} \cdot \mathrm{g}\right)
$$

Po wstawieniu wartości liczbowych $\mathrm{F}_{\mathrm{zmax}}=166868,1$ $\mathrm{N}, \mathrm{m}^{+}=7700 \mathrm{~kg}$ i $\mathrm{g}=9,81 \mathrm{~m} / \mathrm{s}^{2}$ do wzoru (5) otrzymuje się:

$$
\mathrm{F}_{\mathrm{x} 1 \max }=0,1 \cdot(2 \cdot 166868,1+7700 \cdot 9,81)=40927,32 \mathrm{~N} \text {. }
$$

Siły, spowodowane przejazdem wagonu przez tor o wichrowatości $10 \%$ wynikają z wymuszenie kinematycznego działającego na koło, które wyznaczono wg wzoru:

$$
\Delta \mathrm{w}_{\mathrm{m}}=\frac{\mathrm{z} \cdot 2 \mathrm{a}}{4} \cdot \frac{\mathrm{b}}{\mathrm{s}}
$$

gdzie:

-z-wichrowatość toru $[\% 00]$

-2a- baza wózka [mm]

-2b-rozstaw sprężyn I-go stopnia [ $\mathrm{mm}]$

-2s-rozstaw płaszczyzn okręgów tocznych [mm].

Ponieważ wykolejenie odbywa się przy małej prędkości można założyć, że dla wagonu w stanie próżnym jedno koło wózka jest całkowicie odciążone a inne przemieszczone na wysokość główki szyny.

Po wstawieniu wartości liczbowych $\mathrm{z}=0,01,2 \mathrm{a}=2600$ $\mathrm{mm}, \mathrm{b}=1000 \mathrm{~mm}, \mathrm{~s}=750 \mathrm{~mm}$ do wzoru (7) otrzymuje się:

$$
\Delta \mathrm{w}_{\mathrm{m}}=\frac{0,01 \cdot 2600}{4} \cdot \frac{1000}{750}=8,666 \mathrm{~mm}
$$

Schemat obciążeń wózka przedstawiono na rys.6.
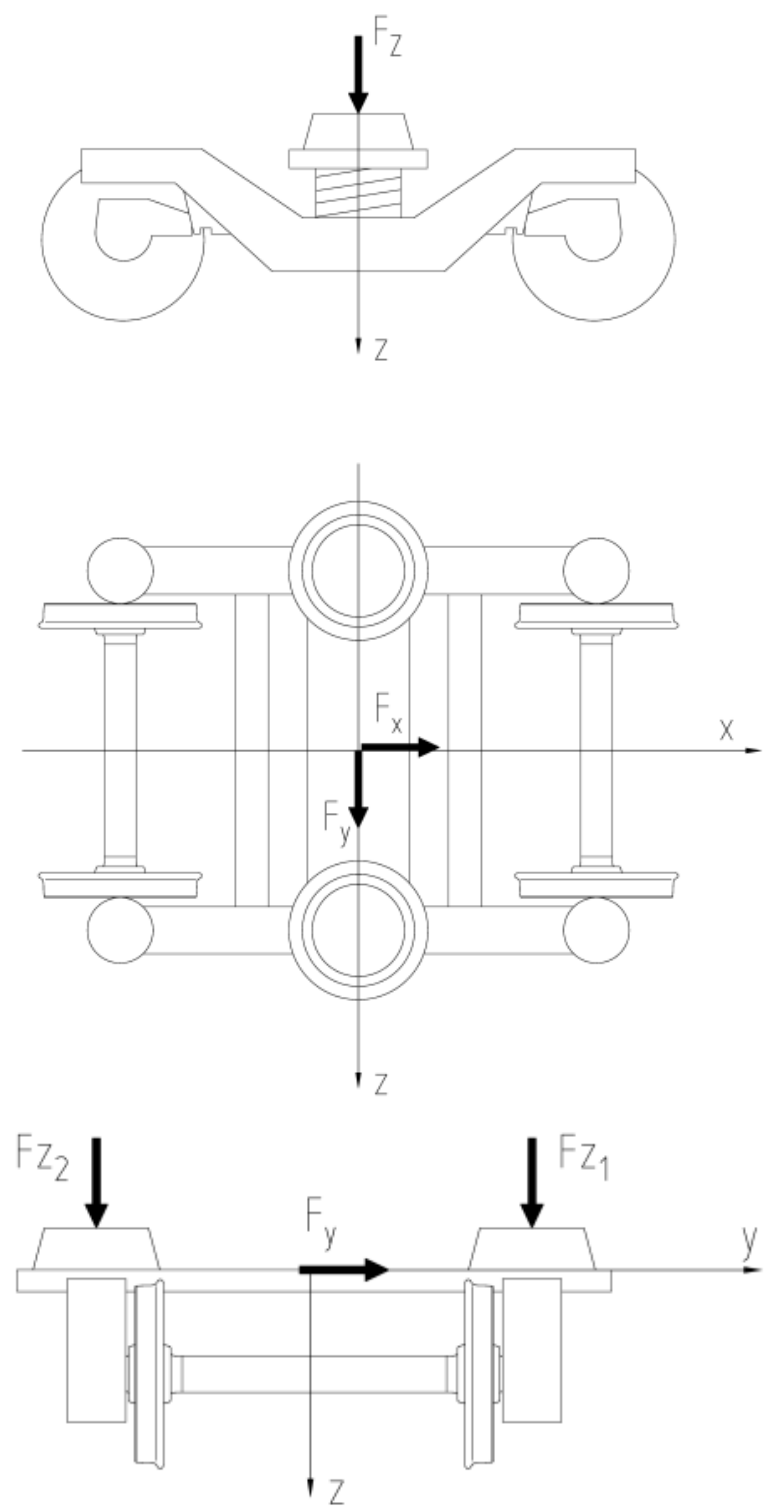

Rys.6. Schemat obciążenia ramy wózka podczas badań statycznych z obciążeniami nadzwyczajnymi i obciążeniami eksploatacyjnymi

\subsubsection{Przebieg badań}

Każdy przypadek obciążenia należy zrealizować przynajmniej dwukrotnie, zwiększając wartość obciążenia następująco:

$$
\mathbf{0} \rightarrow \mathbf{P} / \mathbf{2} \rightarrow \mathbf{P} \rightarrow \mathbf{0}
$$

W przypadku obciążenia bocznego lub od wichrowatości toru należy zrealizować wszystkie możliwe kombinacje obciążeń, wynikające ze zwrotu danego obciążenia. Przy realizacji obciążeń toru należy dodatkowo określić sztywność skrętną ramy. Wartość sztywności skrętnej, wyznaczoną eksperymentalnie wykorzystuje się do weryfikacji obliczeń bezpieczeństwa przed wykolejeniem w warunkach quasistatycznych. 
Tabela 2

\begin{tabular}{|c|c|c|c|}
\hline Typ stali & Grubość elementu & $\mathbf{R}_{\mathbf{e}}[\mathbf{M P a}]$ & $\mathbf{R}_{\mathbf{m}}[\mathbf{M P a}]$ \\
\hline S355J2 & $<16 \mathrm{~mm}$ & 355 & $490 \div 630$ \\
\hline
\end{tabular}

\subsubsection{Kryteria oceny}

Przy badaniu z siłami i wartościach maksymalnych wymienionych we wzorach od (1) do (8) nie moga wystapić przekroczenia granicy plastyczności. Po odciążeniu rama wózka nie może wykazywać żadnych odkształceń trwałych. Rama wózka jest wykonana ze stali S355J2 posiadającej minimalną granice plastyczności $\mathrm{R}_{\mathrm{eH}}=355 \mathrm{MPa}$ wg PN-EN 10025:2007 [16]. Własności wytrzymałościowe stali S355J2 są przedstawione w tabeli 2 .

\subsubsection{Obciążenia statyczne ramy $z$ obciążeniami eksploatacyjnymi \\ 3.3.4.1. Sily podczas badań}

Podczas badań statycznych z symulacją sił występujących w eksploatacji, ramę wózka realizuje się różne przypadki obciążeń wynikających z kombinacji działania sił wymienionych poniżej.

\section{Pionowe obciążenia eksploatacyjne wyznaczono ze}

wzoru:

$$
\mathrm{F}_{\mathrm{Z} 1}=\frac{\left(\mathrm{M}_{\mathrm{V}}+1,2 \mathrm{P}_{2}-2 \mathrm{~m}^{+}\right) \cdot \mathrm{g}}{4}
$$

Po wstawieniu wartości liczbowych $\mathrm{M}_{\mathrm{V}}=49200 \mathrm{~kg}$, $\mathrm{P}_{2}=10600 \mathrm{~kg}, \mathrm{~m}^{+}=7700 \mathrm{~kg}$ i $\mathrm{g}=9,81 \mathrm{~m} / \mathrm{s}^{2}$ otrzymuje się:

$\mathrm{F}_{\mathrm{Z1}}=\frac{(49200+1,2 \cdot 10600-2 \cdot 7700) \cdot 9,81}{4}=114090,3 \mathrm{~N}$

Poprzeczne obciążenia eksploatacyjne wyznaczono ze wzoru:

$$
\mathrm{F}_{\mathrm{y} 1}=\frac{\mathrm{F}_{\mathrm{z}}+\mathrm{m}^{+} \cdot \mathrm{g}}{8}
$$

Po wstawieniu wartości liczbowych $\mathrm{F}_{\mathrm{z}}=2 \mathrm{~F}_{\mathrm{zl}}=$ $2 \cdot 114090,3 \mathrm{~N}, \mathrm{~m}^{+}=7700 \mathrm{~kg}$ i $\mathrm{g}=9,81 \mathrm{~m} / \mathrm{s}^{2}$ do wzoru (11) otrzymuje się:

$$
\mathrm{F}_{\mathrm{y} 1}=\frac{2 \cdot 114090,3+7700 \cdot 9,81}{8}=37964,7 \mathrm{~N}
$$

(12)

Wzdłużne siły skośne eksploatacyjne wyznaczono ze wzoru:

$$
\mathrm{F}_{\mathrm{x} 1 \max }=0,05\left(\mathrm{~F}_{\mathrm{z}}+\mathrm{m}^{+} \cdot \mathrm{g}\right)
$$

Po wstawieniu wartości liczbowych $\mathrm{F}_{\mathrm{Z}}=2 \mathrm{~F}_{\mathrm{Zl}}=$ $2 \cdot 114090,3 \mathrm{~N}, \mathrm{~m}^{+}=7700 \mathrm{~kg}$ i $\mathrm{g}=9,81 \mathrm{~m} / \mathrm{s}^{2}$ do wzoru (13) otrzymuje się:

$$
\mathrm{F}_{\mathrm{x} 1 \max }=0,05(2 \cdot 114090,3+7700 \cdot 9,81)=15185,88 \mathrm{~N}
$$

Siły, spowodowane przejazdem wagonu przez tor o wichrowatości $5 \%$ wynikają $\mathrm{z}$ wymuszenia kinematycznego działającego na koło i które wyznaczono ze wzoru (7):

$$
\Delta \mathrm{w}_{\mathrm{m}}=\frac{0,005 \cdot 2600}{4} \cdot \frac{1000}{750}=4,333 \mathrm{~mm}
$$

\subsubsection{Przebieg badań}

Różne przypadki obciążeń, które należy uwzględnić w statycznych badaniach wytrzymałościowych są przedstawione w tabeli 3 .

\subsubsection{Kryteria oceny wyników badań}

Dla każdego punktu pomiarowego (tensometru) należy z trzynastu przypadków obciążeń (tabela 3) wybrać minimalną wartość ó MIN $\mathrm{i}$ wartość maksymalną zmierzonych naprężeń ómax. $\mathrm{Na}$ ich podstawie należy wyznaczyć:

$\Rightarrow$ średnią wartość naprężeń ó ${ }_{\mathrm{M}}$ :

$$
\sigma_{\mathrm{M}}=\frac{\sigma_{\mathrm{MIN}}+\sigma_{\mathrm{MAX}}}{2}
$$

$\Rightarrow$ amplitudę naprężeń $\Delta$ ó:

$$
\Delta \sigma=\frac{\sigma_{\mathrm{MAX}}-\sigma_{\mathrm{MIN}}}{2}
$$

W oparciu o wykresy Goodmana-Smitha zamieszczone w ERRI B12Rp.17 [32] należy określić naprężenia dopuszczalne ó $_{\text {dop }}$. W tych punktach pomiarowych, w których kierunek naprężeń głównych nie pokrywa się z kierunkiem tensometru, należy uwzględnić wyniki pomiarów dla rozet tensometrycznych, przy których można znaleźć naprężenia główne w danym miejscu pomiarowym. Przy wyznaczaniu średniej wartości naprężeń i amplitudy naprężeń należy stosować metodykę postępowania, przedstawioną w ERRI B12Rp.17 [32]. Na ograniczonej liczbie miejsc pomiarowych dopuszczalne jest przekroczenie naprężeń dopuszczalnych o maksymalnie $20 \%$ pod warunkiem, że w trakcie badań zmęczeniowych 1-go stopnia i 2-giego stopnia nie pojawią się jakiekolwiek pęknięcia a w trzecim stopniu mogą się pojawić tylko takie, które nie wymagają natychmiastowej naprawy. Zapis o dopuszczalnym przekroczeniu naprężeń podczas badań statycznych nie występuje w normie PN-EN 13749:2008 [21], ale jest zamieszczony w przepisach TSI [31] i w karcie UIC 515-4 [11]. Jak pokazuje dotychczasowa 
Przypadki obciążeń dla cyklu kombinacji sil pionowych i poprzecznych oraz wynikających z wichrowatości toru dla statycznych prób wytrzymałościowych z obciążeniami eksploatacyjnymi

Tabela 3

\begin{tabular}{|c|c|c|c|c|}
\hline $\begin{array}{c}\text { Przypadek } \\
\text { obciążenia }\end{array}$ & $\begin{array}{c}\text { Sila pionowa } \\
{[\mathrm{N}]}\end{array}$ & $\begin{array}{c}\text { Sila pionowa } \\
{[\mathrm{N}]}\end{array}$ & Sila poprzeczna $[\mathbf{N}]$ & $\begin{array}{c}\text { Wichrowatośćc } \\
{\left[\%{ }_{00}\right]}\end{array}$ \\
\hline \multirow{2}{*}{1} & $\mathrm{~F}_{\mathrm{z} 1}=0,5 \mathrm{~F}_{\mathrm{z}}$ & $\mathrm{F}_{\mathrm{z} 2}=0,5 \mathrm{~F}_{\mathrm{z}}$ & $\overline{0}$ & \\
\hline & 114090 & 114090 & 0 & \\
\hline \multirow{2}{*}{2} & $(1+\alpha-\beta) \mathrm{F}_{\mathrm{z} 1}=0,9 \mathrm{~F}_{\mathrm{z} 1}$ & $(1-\alpha-\beta) \mathrm{F}_{\mathrm{z} 2}=0,7 \mathrm{~F}_{\mathrm{z} 2}$ & 0 & \\
\hline & 102681 & 79863 & 0 & \\
\hline \multirow{2}{*}{3} & $(1+\alpha-\beta) \mathrm{F}_{\mathrm{z} 1}=0,9 \mathrm{~F}_{\mathrm{z} 1}$ & $(1-\alpha-\beta) \mathrm{F}_{\mathrm{z} 2}=0,7 \mathrm{~F}_{\mathrm{z} 2}$ & $\mathrm{~F}_{\mathrm{y}}$ & \\
\hline & 102681 & 102681 & 37964,7 & \\
\hline \multirow{2}{*}{4} & $(1+\alpha+\beta) \mathrm{F}_{\mathrm{z} 1}=1,3 \mathrm{~F}_{\mathrm{z} 1}$ & $(1-\alpha+\beta) \mathrm{F}_{\mathrm{z} 2}=1,1 \mathrm{~F}_{\mathrm{z} 2}$ & 0 & \\
\hline & 148317 & 125499 & 0 & \\
\hline \multirow{2}{*}{5} & $(1+\alpha+\beta) \mathrm{F}_{\mathrm{z} 1}=1,3 \mathrm{~F}_{\mathrm{z} 1}$ & $(1-\alpha+\beta) \mathrm{F}_{\mathrm{z} 2}=1,1 \mathrm{~F}_{\mathrm{z} 2}$ & $\mathrm{~F}_{\mathrm{y}}$ & \\
\hline & 148317 & 125499 & 37964,7 & \\
\hline \multirow{2}{*}{6} & $(1-\alpha-\beta) \mathrm{F}_{\mathrm{z} 1}=0,7 \mathrm{~F}_{\mathrm{z} 1}$ & $(1+\alpha-\beta) \mathrm{F}_{\mathrm{z} 2}=0,9 \mathrm{~F}_{\mathrm{z} 2}$ & 0 & \\
\hline & 79863 & 102681 & 0 & \\
\hline \multirow{2}{*}{7} & $(1-\alpha-\beta) \mathrm{F}_{\mathrm{z} 1}=0,7 \mathrm{~F}_{\mathrm{z} 1}$ & $(1+\alpha-\beta) \mathrm{F}_{\mathrm{z} 2}=0,9 \mathrm{~F}_{\mathrm{z} 2}$ & $-\mathrm{F}_{\mathrm{y}}$ & \\
\hline & 79683 & 102681 & $-37964,7$ & \\
\hline \multirow{2}{*}{8} & $(1-\alpha+\beta) \mathrm{F}_{\mathrm{z} 1}=1,1 \mathrm{~F}_{\mathrm{z} 1}$ & $(1+\alpha+\beta) \mathrm{F}_{\mathrm{z} 1}=1,3 \mathrm{~F}_{\mathrm{z} 2}$ & 0 & \\
\hline & 125499 & 148317 & 0 & \\
\hline \multirow{2}{*}{9} & $(1-\alpha+\beta) \mathrm{F}_{\mathrm{z} 1}=1,1 \mathrm{~F}_{\mathrm{z} 1}$ & $(1+\alpha+\beta) \mathrm{F}_{\mathrm{z} 1}=1,3 \mathrm{~F}_{\mathrm{z} 2}$ & $-\mathrm{F}_{\mathrm{y}}$ & \\
\hline & 125499 & 148317 & $-37964,7$ & \\
\hline \multirow{3}{*}{10} & $(1+\alpha-\beta) \mathrm{F}_{\mathrm{z} 1}=0,9 \mathrm{~F}_{\mathrm{z} 1}$ & $(1-\alpha-\beta) \mathrm{F}_{\mathrm{z} 2}=0,7 \mathrm{~F}_{\mathrm{z}}$ & $\mathrm{F}_{\mathrm{y}}$ & \multirow{3}{*}{ $\pm 5 \%$} \\
\hline & & & & \\
\hline & 102681 & 79863 & 37964,7 & \\
\hline \multirow{2}{*}{11} & $(1+\alpha+\beta) \mathrm{F}_{\mathrm{z} 1}=1,3 \mathrm{~F}_{\mathrm{z} 1}$ & $(1-\alpha+\beta) \mathrm{F}_{\mathrm{z} 2}=1,1 \mathrm{~F}_{\mathrm{z} 2}$ & $\mathrm{~F}_{\mathrm{y}}$ & \multirow{2}{*}{ $\pm 5 \%$} \\
\hline & 148317 & 125499 & 37964,7 & \\
\hline \multirow{2}{*}{12} & $(1-\alpha-\beta) \mathrm{F}_{\mathrm{z} 1}=0,7 \mathrm{~F}_{\mathrm{z} 1}$ & $(1+\alpha-\beta) \mathrm{F}_{\mathrm{z} 2}=0,9 \mathrm{~F}_{\mathrm{z} 2}$ & $\mathrm{~F}_{\mathrm{y}}$ & \multirow{2}{*}{ $\pm 5 \%$} \\
\hline & 79863 & 102681 & 37964,7 & \\
\hline \multirow{2}{*}{13} & $(1-\alpha+\beta) \mathrm{F}_{\mathrm{z} 1}=1,1 \mathrm{~F}_{\mathrm{z} 1}$ & $(1+\alpha+\beta) \mathrm{F}_{\mathrm{z} 1}=1,3 \mathrm{~F}_{\mathrm{z} 2}$ & $\mathrm{~F}_{\mathrm{y}}$ & \multirow{2}{*}{ $\pm 5 \%$} \\
\hline & 125499 & 148317 & 37964,7 & \\
\hline
\end{tabular}

\section{Oznaczenia użyte w tabeli 3}

- $\alpha=0$, 1: wspótczynnik wynikający z efektu kotysania wagonu osobowego $w$ stosunku do nacisku pionowego - $\beta=0,2$ : współczynnik wynikajacy z efektu podskakiwanie wagonu osobowego w stosunku do nacisku pionowego.

praktyka badawcza takie przekroczenia naprężeń $\mathrm{W}$ ramach podczas badań statycznych występowały, natomiast rama wózka przy poprawnym wykonaniu spoin przechodziła badania zmęczeniowe $\mathrm{z}$ wynikiem pozytywnym.
Przypadki obciążeń dla cyklu kombinacji sił pionowych i wzdłużnych podczas prób nabiegania są przestawione w tabeli 4. 
Przypadki obciążeń dla cyklu kombinacji sił pionowych i wzdłużnych wynikających z nabiegania dla statycznych prób wytrzymałościowych z obciążeniami eksploatacyjnymi

Tabela 4

\begin{tabular}{|c|c|c|c|}
\hline Przypadek obciążenia & $\begin{array}{c}\text { Sila pionowa } \\
{[\mathbf{N}]}\end{array}$ & $\begin{array}{c}\text { Sila pionowa } \\
{[\mathbf{N}]}\end{array}$ & $\begin{array}{c}\text { Sila wzdlużna } \\
{[\mathbf{N}]}\end{array}$ \\
\hline \multirow{2}{*}{$\mathbf{1}$} & $\mathrm{F}_{\mathrm{z} 1}$ & $\mathrm{~F}_{\mathrm{z} 2}$ & 0 \\
\cline { 2 - 4 } & 114090 & 114090 & $\mathrm{~F}_{\mathrm{x} 1}$ \\
\hline \multirow{2}{*}{$\mathbf{2}$} & $\mathrm{F}_{\mathrm{z} 1}$ & $\mathrm{~F}_{\mathrm{z} 2}$ & 15186 \\
\cline { 2 - 4 } & 114090 & 114090 & $-\mathrm{F}_{\mathrm{x} 1}$ \\
\hline \multirow{2}{*}{$\mathbf{3}$} & $\mathrm{F}_{\mathrm{z} 1}$ & $\mathrm{~F}_{\mathrm{z} 2}$ & -15186 \\
\cline { 2 - 4 } & 114090 & 114090 & \\
\hline
\end{tabular}

\subsubsection{Kryteria oceny wyników badań}

Dla każdego punktu pomiarowego (tensometru) należy z trzynastu przypadków obciążeń (tabela 3) wybrać minimalną wartość ó MIN $\mathrm{i}$ wartość maksymalną zmierzonych naprężeń ó MAX $\mathrm{Na}$ ich podstawie należy wyznaczyć:

$\Rightarrow$ średnią wartość naprężeń ó $\mathrm{o}_{\mathrm{M}}$ :

$$
\sigma_{\mathrm{M}}=\frac{\sigma_{\mathrm{MIN}}+\sigma_{\mathrm{MAX}}}{2}
$$

$\Rightarrow$ amplitudę naprężeń $\Delta$ ó:

$$
\Delta \sigma=\frac{\sigma_{\mathrm{MAX}}-\sigma_{\mathrm{MIN}}}{2}
$$

W oparciu o wykresy Goodmana-Smitha zamieszczone w ERRI B12Rp.17 [32] należy określić naprężenia

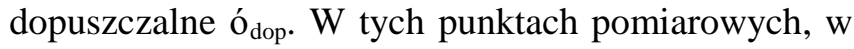
których kierunek naprężeń głównych nie pokrywa się z kierunkiem tensometru, należy uwzględnić wyniki pomiarów dla rozet tensometrycznych, przy których można znaleźć naprężenia główne w danym miejscu pomiarowym. Przy wyznaczaniu średniej wartości naprężeń $\mathrm{i}$ amplitudy naprężeń należy stosować metodykę postępowania, przedstawioną w ERRI B12Rp.17 [32]. Na ograniczonej liczbie miejsc pomiarowych dopuszczalne jest przekroczenie naprężeń dopuszczalnych o maksymalnie $20 \%$ pod warunkiem, że w trakcie badań zmęczeniowych 1-go stopnia i 2-giego stopnia nie pojawią się jakiekolwiek pęknięcia a w trzecim stopniu mogą się pojawić tylko takie, które nie wymagają natychmiastowej naprawy. Zapis o dopuszczalnym przekroczeniu naprężeń podczas badań statycznych nie występuje w normie PN-EN 13749:2008 [21], ale jest zamieszczony w przepisach TSI [31] i w karcie UIC 515-4 [11]. Jak pokazuje dotychczasowa praktyka badawcza takie przekroczenia naprężeń $\mathrm{w}$ ramach podczas badań statycznych występowały, natomiast rama wózka przy poprawnym wykonaniu spoin przechodziła badania zmęczeniowe $\mathrm{z}$ wynikiem pozytywnym.

\subsubsection{Obciążenia podczas badań zmęczeniowych 3.3.5.1. Sily podezas badań}

W takcie badań zmęczeniowych rama wózka poddawana jest działaniu obciążenia pionowego, bocznego i od wichrowatości toru $\pm 5 \%$. Wartość całkowita siły pionowej lub bocznej (przy uwzględnieniu $\mathrm{F}_{\mathrm{z}}=114090,3 \mathrm{~N}, \alpha=0,1, \beta=0,2, \mathrm{~m}^{+}=7700 \mathrm{~kg}$ oraz $\mathrm{g}=9,81$ $\mathrm{m} / \mathrm{s}^{2}$ ) jest efektem nakładania się następujących składowych sił pionowych $\mathrm{z}$ podziałem na:

$\Rightarrow$ udział statyczny: $\mathrm{F}_{\mathrm{z} 1}=\mathrm{F}_{\mathrm{z} 2}=0,5 \mathrm{~F}_{\mathrm{z}}=114090,3 \mathrm{~N}$

$\Rightarrow$ udział quasi-statyczny: $\quad \mathrm{F}_{\mathrm{zqs} 1}=\mathrm{F}_{\mathrm{zqs} 2}= \pm 0,5 \alpha \mathrm{F}_{\mathrm{z}}=$ $\pm 11409 \mathrm{~N}$

$\Rightarrow$ udział dynamiczny: $\mathrm{F}_{\mathrm{zd} 1}=\mathrm{F}_{\mathrm{zd} 2}= \pm 0,5 \beta \mathrm{F}_{\mathrm{z}}= \pm 22818$

$\mathrm{N}$ oraz sił bocznych z podziałem na:

$\Rightarrow$ udział quasi-statyczny: $\mathrm{F}_{\mathrm{yqs} 1}=\mathrm{F}_{\mathrm{yqs} 2}= \pm 0,05$

$\left(\mathrm{F}_{\mathrm{z}}+\mathrm{m}^{+} \mathrm{g}\right)=15185,88 \mathrm{~N}$

$\Rightarrow$ udział dynamiczny: $\mathrm{F}_{\mathrm{yd} 1}=\mathrm{F}_{\mathrm{yd} 2}= \pm 0,05\left(\mathrm{~F}_{\mathrm{z}}+\mathrm{m}^{+} \mathrm{g}\right)=$ $15185,88 \mathrm{~N}$.

Zmiany obciążeń dynamicznych pionowych oraz bocznych muszą zachodzić przy zachowaniu równej częstotliwości i bez przesunięcia fazowego. Siła quasistatyczna pionowa i boczna symulują jazdę w huku toru, na zmianę w lewym i prawym i są ze sobą zsynchronizowane.

\subsubsection{Przebieg badań}

Cały cykl badań jest podzielony na trzy stopnie obciążenia. Łączna liczba cykli obciążeń dynamicznych w pierwszym stopniu wynosi $6 \times 10^{6}$ cykli. $\mathrm{W}$ drugim stopniu obciążenia wartość sił quasistatycznych pozostaje niezmieniona, natomiast wartość sił dynamicznych zwiększa się 1,2 razy. Ilość cykli w drugim stopniu obciążenia wynosi $2 \times 10^{6}$. W trzecim stopniu obciążenia wartość sił quasistatycznych pozostaje niezmieniona, natomiast wartość sił dynamicznych zwiększa się 1,4 razy. Poszczególne cykle badawcze są przedstawione na rys. 7 . 


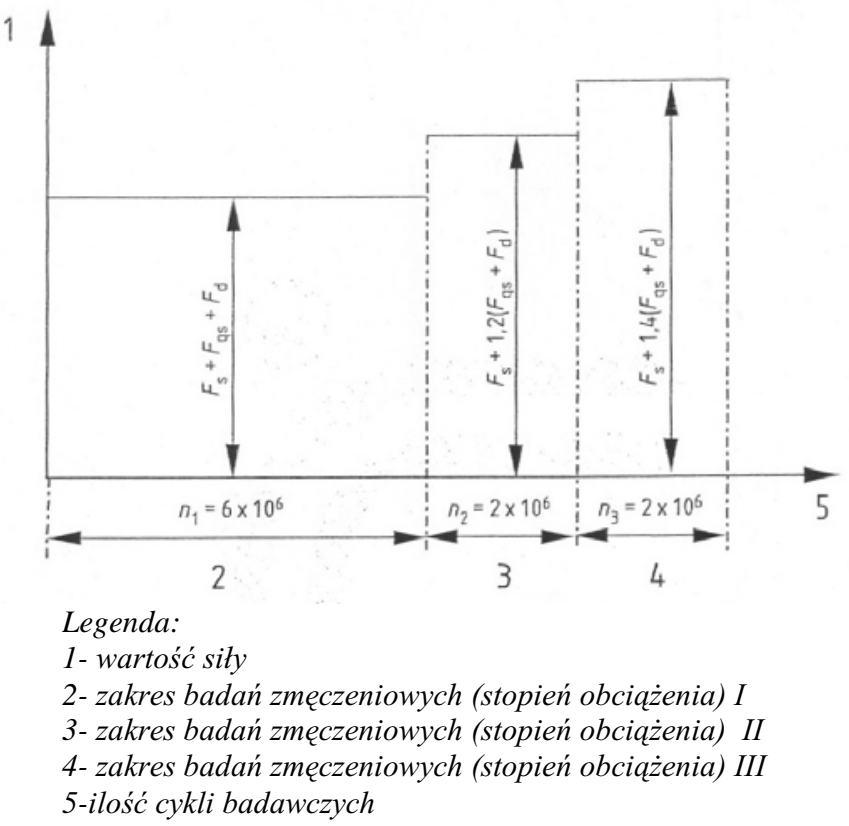

Rys.7. Podział badań zmęczeniowych ramy wózka na trzy zakresy badawcze

Przebieg sił pionowych i bocznych w zależności od ilości cykli przedstawiono na rys. 8 .

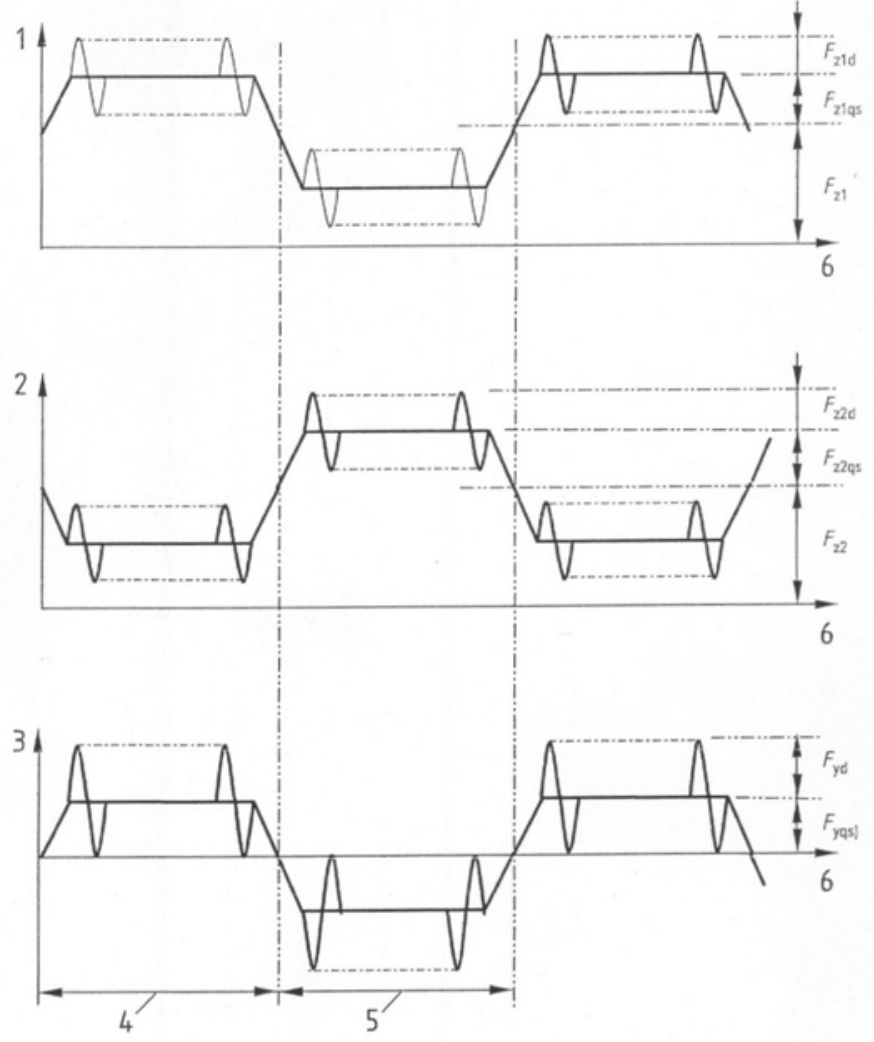

Rys.8 Przebieg sił pionowych i poprzecznych obciążających ramę w funkcji czasu

Opis oznaczeń użytych na rys.8:

1- siła pionowa przyłożona do pierwszej ostojnicy $F_{z 1}$

2- siła pionowa przyłożona do drugiej ostojnicy $F_{z 2}$

3- sita poprzeczna $F_{y}$

4- $n$ cykli tuków prawych

5- $n$ cykli tuków lewych

6- ilość cykli badawczych

$F_{z l d}$-sila dynamiczna przytożona do ostojnicy 1

$F_{z d 2}$-siła dynamiczna przyłożona do ostojnicy 2
$F_{x l q s}$-siła quasi-statyczna przytożona do ostojnicy 1

$F_{x 2 q s}$-sita quasi-statyczna przytożona do ostojnicy 2

$F_{y q s^{-}}$statyczna siła poprzeczna

$F_{y d^{-}}$statyczna siła dynamiczna.

W każdym stopniu obciążenia I, II oraz III równocześnie z siłami pionowymi oraz poprzecznymi powinny być wprowadzone obciążenia od zwichrowania toru 5 $\%$. Obciążenie od wichrowatości toru należy wprowadzić w następujący sposób:

$\Rightarrow \mathrm{w}$ stopniu obciążenia I należy wprowadzić $6 \times 10^{5}$ cykli, podzielonych na 10 grup i powtarzanych w równomiernych odstępach przez cały czas realizacji tego stopnia

$\Rightarrow$ w 2-gim i 3-cim stopniu obciążenia należy wprowadzić $2 \times 10^{5}$ cykli w sposób analogiczny jak powyżej.

Badania zmęczeniowe należy przeprowadzić w sposób ciagły, ograniczając do minimum ilość ewentualnych przerw w realizacji poszczególnych stopni obciążeń. Podczas „każdej przerwy badawczej” następuje umocnienie materiału, które wpływa korzystnie na własności wytrzymałościowe. Badania zmęczeniowe muszą być przeprowadzone w taki sposób, aby zagwarantować powtarzalność uzyskanych wyników badań i wyeliminować zjawiska przypadkowe, mające wpływ na uzyskane wyniki.

Jeśli na podstawie wyników statycznych badań wytrzymałościowych stwierdzono, że naprężenia wywołane skręcaniem ramy od wichrowatości toru pojawiają się w tych samych miejscach co naprężenia od obciążenia pionowego i bocznego oraz są znacząco małe w stosunku do nich, wówczas wszystkie te obciążenia muszą być wprowadzone z jednakową częstotliwością i bez przesunięcia fazowego. W przypadku, gdy naprężenia te występują $\mathrm{w}$ różnych miejscach, wówczas obciążenie skrętne można wprowadzić w sposób niezwiązany z pozostałymi. Jeśli $\mathrm{z}$ wyników badań statycznych wynika, że poziom naprężeń wywołany skręcaniem ramy jest mały w porównaniu $\mathrm{z}$ naprężeniami pochodzącymi od pozostałych obciążeń to $\mathrm{W}$ badaniach zmęczeniowych można pominąc obciążenia wywołane wichrowatością toru. Przed rozpoczęciem prób należy pomierzyć wartości naprężeń w tensometrach, dla dowolnego przypadku obciążenia wg tabeli 3 z kombinacją sił: pionowej, bocznej i od wichrowatości toru następnie porównać je $\mathrm{z}$ odpowiednimi wynikami pomiarów z badań statycznych z siłami nadzwyczajnymi i siłami eksploatacyjnymi. Należy w ten sposób przeprowadzić ocenę poprawności obciążenia ramy w badaniach dynamicznych i w przypadku rozbieżności dokonać korekty w wartościach sił obciążających ramę ( np. wymiar 163,5mm na rys.6) lub w punktach jej przyłożenia tak, aby w odpowiednich sobie punktach tensometrycznych uzyskać podobne wartości naprężeń. Siłę pionową $F_{z}$ należy przykładać do ostojnicy poprzez okragłą podkładkę o średnicy zewnętrznej $442 \mathrm{~mm}$ i wewnętrznej $330 \mathrm{~mm}$ imitująca 
pośrednictwo sprężyny głównej $\mathrm{w}$ drugim stopniu usprężynowania. Rama wózka w miejscu działania usprężynowania I-go stopnia powinna być podparta na tulei o średnicy zewnętrznej ok. $250 \mathrm{~mm}$. W czasie badań mierzy się naprężenia maksymalne w sposób statyczny w celu kontroli niezmienności obciążeń oraz w celu wykrycia fragmentów ramy, które tracą nośność na wskutek uszkodzenia nie wykrytego innym sposobem. Sposób obciążenia ramy do badań zmęczeniowych jest przedstawiony na rys.9.

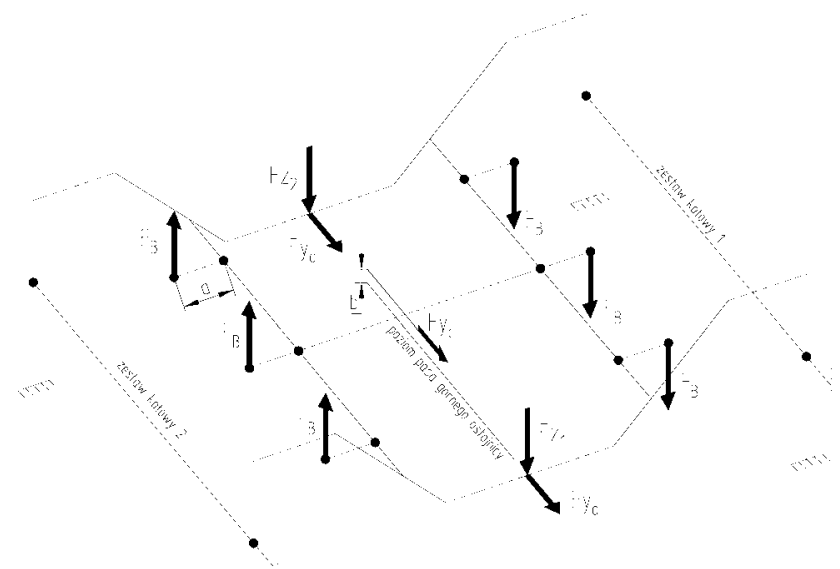

Legenda: wymiary a i b określa się na podstawie dokumentacji konstrukcyjnej wózka 11ANc

Rys.9. Schemat obciążenia ramy siłami pionowymi, poprzecznymi i siłami hamulcowymi wózka podczas badań zmęczeniowych

Udział sił hamulcowych podczas badań zmęczeniowych można pominąć zgodnie z przepisami karty UIC 515-4 [11] oraz PN-EN 13749:2008 [21], o ile ich udział w wytężeniu materiału w poszczególnych punktach pomiarowych jest mały $\mathrm{w}$ porównaniu $\mathrm{z}$ innymi siłami. Oceny tej należy dokonać po badaniach statycznych z obciążeniami nadzwyczajnymi oraz $\mathrm{z}$ obciążeniami eksploatacyjnymi.

\subsubsection{Kryteria oceny}

Wynik badań zmęczeniowych ramy wózka $11 \mathrm{ANc}$ uważa się za pozytywny, jeśli spełnione zostały następujące warunki:

$\Rightarrow$ nie wystapiły żadne pęknięcia po zakończeniu I i II zakresu badań (stopni obciążenia)

$\Rightarrow \mathrm{w}$ trakcie trzeciego stopnia wystapiły nieznaczne pęknięcia zmęczeniowe, które nie wymagają natychmiastowej naprawy podczas eksploatacji.

Kryterium oceny sformułowane na podstawie karty UIC 515-4 [11] oraz PN-EN 13749:2008 [21] i obowiązujące dla III-go stopnia badań nie jest jednoznaczne. Pojęcie to bez szczegółowego zdefiniowania daje rozległą możliwość jego interpretacji dla laboratoriów badawczych i to nie zawsze w sposób prawidłowy. Zagadnienie to nabiera jeszcze większego zna- czenia dla układów biegowych dla taboru napędnego oraz tocznego, przystosowanego do wysokich prędkości, gdzie bezpieczeństwo eksploatacyjne nabiera szczególnego znaczenia. Z praktyki badawczej wynika, że występowały ramy (jako prototypowe obiekty dostarczone do badań) które przeszły wszystkie trzy zakresy badawcze (stopnie obciążeń). Charakteryzowały się one bardzo dobrą technologia wykonania, zwłaszcza w zakresie techniki spawalniczej. Występujące pęknięcia w III stopniu mają charakter poznawczy i na ich podstawie działy konstrukcyjno, technologiczne i kontroli jakości producenta powinny zwrócić szczególną uwagę na „słabe miejsca w konstrukcji”. Powtarzanie badań w tym przypadku nie jest konieczne. Kontrolę spoin, w celu wykrycia ewentualnych spoin należy wykonać co $10^{5}$ metodą wizualną VT oraz co $10^{6}$ cykli metoda penetracyjną PT. Metoda penetracyjna opiera się na wykorzystaniu zjawiska włoskowatości, który polega na wnikaniu cieczy do wąskich przestrzeni i wznoszenia się w kierunku przeciwnym do działania siły ciężkości. Na odpowiednio przygotowaną powierzchnię, czyli suchą i odtłuszczoną nanosi się penetrant, czyli drobnocząsteczkową zawiesinę o kolorze czerwonym lub niebieskim. Zawiesina ta wnika $\mathrm{w}$ szczeliny i po czasie penetracji jest usuwania wyłącznie z powierzchni. Po czasie wywoływania 5 $\div 60$ minut środek penetrujący dyfunduje do szczelin i zabarwi lokalnie wywoływacz wskazując jednocześnie miejsca wystąpienia ewentualnych nieciaggłości materiału ( pęknięć).

\section{Wnioski}

Badania ramy wózka $11 \mathrm{ANc}$ są jednymi $\mathrm{z}$ podstawowych, warunkujących badania dynamiczne na trasie wg karty UIC 518 [12] oraz PN-EN 14363:2005 [22] przy założeniu ekwiwalentnej stożkowatości wg [2], tym bardziej że wagon będzie badany z prędkością $250 \mathrm{~km} / \mathrm{h}$. Zgodnie $\mathrm{z}$ ww. dokumentami prędkość badawcza może przekraczać o $10 \%$ ww. prędkość konstrukcyjną, co sprowadza się do jazdy wagonu jako obiektu badawczego z prędkością $275 \mathrm{~km} / \mathrm{h}$. W związku z tym należy zabezpieczyć maksymalną niezawodność poszczególnych komponentów w tym i ramy jako podstawowego ustroju nośnego. Ostatnie tendencje w rozwoju wózków pojazdów szynowych zmierzają w kierunku uwzględniania większej ilości sił, działających na ramę, aby poznać również lokalną odporność konstrukcji np. w rejonie przyspawanych wsporników do mocowania mechanizmów zaciskowych, tłumików hydraulicznych, stabilizatorów pochylania itd. Wówczas konstrukcja ramy jest przebadana w sposób kompleksowy. Wymaga to jednak znacznie większej ilości siłowników oraz bardziej skomplikowanego oprzyrządowania, co znacznie zwiększa koszty badań. Tendencje te są uzasadnione również tym, że trudno jest utrzymać wysoki poziom 
spawania na całym badanej ramie, co potwierdzają dotychczasowe doświadczenia zdobyte w laboratoriach badawczych. Zwiększone wymagania dotyczące pojazdów wysokich prędkości są podyktowane spełnieniem wymagań TSI oraz RIC [30], dotyczących komunikacji międzynarodowych. Stanowiskowe badania wytrzymałościowe należy powtórzyć w następujących przypadkach:

$>$ w przypadku negatywnego wyniku badań na pierwszym prototypowym egzemplarzu ramy ( np. pęknięcia w I i II stopniu obciążeń lub utratę nośności ramy wózka w III stopniu)

$>\mathrm{w}$ przypadku wprowadzenia istotnych zmian konstrukcyjnych, które wpływają w sposób znaczący na wytrzymałość statyczną i zmęczeniową

$>\mathrm{w}$ przypadku zmiany technologii u tego samego producenta

$>$ w przypadku zmiany producenta.

Stanowiskowe badania wytrzymałościowe ram wózków nowej generacji mają poważny wpływ na bezpieczeństwo eksploatowanego taboru i wymaga wnikliwej analizy przy opracowaniu programu badawczego przez działy konstrukcyjne oraz dużego doświadczenia laboratoriów badawczych, odpowiedzialnych za przeprowadzenie badań.

\section{Literatura}

[1] Handkiewicz J.: Obliczenia wytrzymałościowe ramy wózka 11ANc. 09-12.2007.OR-9257(dokument przechowywany w archiwum IPS ,,Tabor” Poznań).

[2] Sobaś M.: Ekwiwalentna stożkowatość styku koło-szyna $i$ jej znaczenie we współczesnej analizie własności dynamicznych pojazdu szynowego. Pojazdy Szynowe Nr 1/2005.

[3] Sobaś M.: Rozwiazania konstrukcyjne układów biegowych wagonów osobowych przystosowanych do wysokich prędkości. Pojazdy Szynowe Nr 4/2008.

[4] Sobaś M.: Tendencje rozwojowe, wytyczne dla projektowania i kryteria oceny ukladów biegowych wagonów osobowych przeznaczonych do wysokich prędkości. Pojazdy Szynowe $\mathrm{nr}$ 1/2009.

[5] Sobaś M.: Wózek 11ANc dla wagonu osobowego przeznaczonego do wysokich prędkości. Pojazdy Szynowe $n r$ $3 / 2009$.

[6] Tauscher H.: Dauerfestigkeit von Stahl und Gusseisen. 4-te neuaufbearbeitete Auflage, Leipzig 1982.

[7] Wittenbeck L., Sobaś M.: Analiza modalna bezprzedziałowego wagonu osobowego 150A w celu przystosowania jego struktury nośnej do wózków wysokich prędkości typu 11ANc. Pojazdy Szynowe nr 2/2009

[8] Wittenbeck L., Sobaś M.: Analiza modalna bezprzedziatowego wagonu osobowego. XVIII Konferencja Pojazdów Szynowych. Materiaty konferencyjne Politechniki Ślaskiej. Katowice-Ustroń 17-19.09.2008

[9] Karta UIC 505-1: Pojazdy kolejowe. Skrajnia pojazdów. 10-te wydanie z maja 2006

[10] Karta UIC 510-2: Pojazdy doczepne. Warunki dla stosowania kół o różnych średnicach $w$ układach biegowych różnego typu. 4-te wydanie, kwiecień 2002.

[11] Karta UIC 515-4: Pojazdy kolejowe dla transportu pasazerów. Wózki toczne. Układy biegowe. Badania wytrzymałościowe ram wózków. 1-sze wydanie z dnia 1.01.1993.

[12] Karta UIC 518: Badania i homologacja pojazdów szynowych z punktu widzenia właściwości dynamicznych, bezpieczeństwa jazdy, obciqżenia toru i parametrów biego- wych. 3-cie wydanie, październik 2005.

[13] Karta UIC 567-2: Zunifikowane wagony pasażerskie typu $Z$ dopuszczone do ruchu międzynarodowego. Charakterystyki. 4-te wydanie z 1.07.1991 ze zmiana 1.07.1995.

[14] Karta UIC 660: Przepisy dotyczace zapewnienia technicznej kompatybilności dla pociqgów dostosowanych do wysokich prędkości. Wydanie 2, sierpień 2002.

[15] Karta UIC 897-13: Warunki techniczne dla kontroli jakości złacz spawanych części pojazdów ze stali. 2-gie wydanie z 1.01.1992.

[16] PN-EN 10025-2:2007: Wyroby walcowane na gorqco ze stali konstrukcyjnych-Część 2:

Warunki techniczne dostawy stali konstrukcyjnych niestopowych.

[17] PN-EN 13103: 2003: Zestawy kołowe i wózki. Osie zestawów kołowych tocznych. Zasady konstrukcji.

[18] PN-EN 13261:2004: Kolejnictwo-Zestawy kołowe i wózki Osie. Wymagania dotyczace wyrobu.

[19] PN-EN 13262:2007: Kolejnictwo. Zestawy kołowe i wózki. Koła. Wymagania dotyczace wyrobu.

[20] PN-EN 13715: 2006: Kolejnictwo. Zestawy kołowe i wózki. Koła. Zarys zewnętrzny koła

[21] PN-EN 13749:2008: Kolejnictwo. Zestawy kołowe i wózki. Metody określania wymagań konstrukcyjnych dla ram wózków.

[22] PN-EN 14363:2005: Kolejnictwo. Badania własności dynamicznych przed dopuszczeniem pojazdów szynowych. Badania własności biegowych i próby stacjonarne.

[23] PN-EN 15085-1:2007:Kolejnictwo. Spawanie pojazdów szynowych i ich części składowych. Część 1: Postanowienia ogólne.

[24] PN-EN 15085-2:Kolejnictwo. Spawanie pojazdów szynowych i ich części sktadowych. Część 2: Wymagania dotyczace jakości i certyfikacja zaktadów spawalniczych.

[25] PN-EN 15085-3:Kolejnictwo. Spawanie pojazdów szynowych i ich części sktadowych. Część 3: Wymagania konstrukcyjne.

[26] PN-EN 15085-4:Kolejnictwo. Spawanie pojazdów szynowych i ich części składowych. Część 4: Wymagania produkcyjne.

[27] PN-EN 15085-5: Kolejnictwo. Spawanie pojazdów szynowych i ich części składowych. Część 5: Kontrola, badania $i$ dokumentacja

[28] prEN 15827: Kolejnictwo. Wózki i układy biegowe.

[29] PN-ISO 3755:1994: Staliwo konstrukcyjne ogólnego przeznaczenia.

[30] Przepisy RIC: Umowa o wymianie i użytkowaniu wagonów pasażerskich $w$ komunikacji międzynarodowej. Ważna od 1 stycznia 2001.

[31] Przepisy TSI: Decyzja komisji dotyczaca specyfikacji interoperacyjności odnoszacej się do podsystemu „tabor kolejowy-wagony towarowe" transeuropejskiego systemu kolei konwencjonalnych z dnia 26 lipca 2006. Dziennik Urzędowy Unii Europejskiej.

[32] Raport ORE/ERRI B12/Rp.17 wydanie 8: Program prób $i$ badań dla wagonów towarowych z podwoziem i struktura wagonu ze stali (które nadaja się do zabudowy sprzegu automatycznego pracujacego na rozciaganie $i$ ściskanie) $i$ których wózki maja ramę stalowq. Utrecht, kwiecień 1997.

[33] Raport ORE/ERRI B12/Rp.60: Badania wytrzymatościowe pojazdów szynowych. Przepisy dotyczqce badań wytrzymatościowych pojazdów szynowych. Przepisy dotyczqce realizacji i dopuszczalnych naprężeń. Utrecht, 06.1995. 